\title{
Glucose Promotes Survival of Rat Pancreatic $\beta$ Cells by Activating Synthesis of Proteins Which Suppress a Constitutive Apoptotic Program
}

\author{
Anne Hoorens, Mark Van de Casteele, Gunter Klöppel, and Daniel Pipeleers \\ Diabetes Research Center, Vrije Universiteit Brussel, B-1090 Brussels, Belgium
}

\begin{abstract}
This study demonstrates that rat islet $\beta$ cells constitutively express an apoptotic program which is activated when mRNA or protein synthesis is blocked. Apoptotic $\beta$ cells were detectable by electron microscopy after treatment with actinomycin D or cycloheximide. With a fluorescence microscopic assay both agents were found to increase the number of apoptotic $\beta$ cells dose- and time-dependently, up to $70 \%$ after $1 \mathrm{wk}$ of culture; virtually no apoptotic $\beta$ cells occurred in control preparations or in conditions leading to primary necrosis. Thus, survival of $\beta$ cells seems dependent on synthesis of proteins which suppress an endogenous suicide program. This mechanism explains earlier observed effects of glucose on survival of cultured $\beta$ cells. Glucose is known to dose-dependently increase the percentage of $\beta$ cells in active biosynthesis and the percentage that survives during culture. It is now demonstrated that the glucose-induced survival of $\beta$ cells cultured for 1 wk results from a dose-dependent reduction in the percentage of $\beta$ cells dying in apoptosis $(49 \%$ at $3 \mathrm{mM}$ glucose, $40 \%$ at $6 \mathrm{mM}, 9 \%$ at 10 $\mathrm{mM})$. Thus, intercellular differences in glucose sensitivity appear responsible for the heterogeneity in $\beta$ cell sensitivity to apoptotic conditions. These data indicate that glucose promotes survival of $\beta$ cells by activating synthesis of proteins which suppress apoptosis. The present model allows for further investigation of the regulation of apoptosis in $\beta$ cells and the identification of agents which induce or prevent $\beta$ cell death. (J. Clin. Invest. 1996. 98:1568-1574.) Key words: apoptosis - insulin - endocrine pancreas - diabetes • islets of Langerhans
\end{abstract}

\section{Introduction}

Apoptosis is a genetically and metabolically controlled mechanism of cell death. Its causes differ from those of necrosis, which provoke cell death through acute injury. Since apoptosis is implicated in normal cell turnover and involution, it plays an important role in tissue homeostasis and development $(1,2)$. A variety of extrinsic and intrinsic factors can trigger apoptosis through activation of an internally encoded suicide program $(2,3)$. In some instances, this process can be suppressed by inhibitors of RNA or protein synthesis, suggesting induction af-

Address correspondence to D. Pipeleers, Diabetes Research Center, Vrije Universiteit Brussel, Laarbeeklaan 103, B-1090 Brussels, Belgium. Phone: 32-2-4774541; FAX: 32-2-4774545; E-mail: dpip@mebo.vub.ac.be Received for publication 14 May 1996 and accepted in revised form 29 July 1996

J. Clin. Invest.

(C) The American Society for Clinical Investigation, Inc. 0021-9738/96/10/1568/07 \$2.00

Volume 98, Number 7, October 1996, 1568-1574 ter specific proteins are expressed (4). In other conditions, these inhibitors induce apoptosis, indicating that its program is constitutively expressed but suppressed by endogenous proteins (2, 3, 5-9). In a number of mammalian cell types, autocrine or paracrine signals appear required to suppress the constitutive suicide program; deprivation of these survival signals will then result in activation of the program $(2,3,10)$. It is conceivable that such a mechanism is responsible for disorders with massive cell losses (11). Insulin-dependent diabetes is caused by death of the majority of insulin-producing $\beta$ cells $(12,13)$, but it is unknown whether apoptosis is an underlying event. It is also unclear to which extent and through which mechanism this form of cell death occurs in the life cycle of the normal pancreatic $\beta$ cell population. We observed recently that nutrients and hormones enhance the survival of rat $\beta$ cells in culture (14), but the action mechanism of these survival factors has not been identified yet. It is conceivable that some of these agents suppress apoptosis and, hence, prolong survival of $\beta$ cells. To assess the rationale for such study, we have investigated the existence of a constitutive apoptotic program in pancreatic $\beta$ cells. An experimental model is developed in which the number of apoptotic cells can be quantified during culture so that the regulation by extrinsic and intrinsic factors can be examined.

\section{Methods}

Preparation of $\beta$ cells. Pancreatic islets were isolated from adult male Wistar rats as described previously (15). Islet cell suspensions were obtained by dissociation of freshly isolated islets in calcium-free medium, first in the absence and then in the presence of trypsin and DNase (15). Preparations of single $\beta$ cells were collected after autofluorescence-activated sorting of the dissociated cells (15). The purified cells were cultured as single cells or as aggregates.

Culture. $\beta$ cells were distributed over polylysin-coated microtiter cups $\left(3 \times 10^{3}\right.$ cells/cup with $200 \mu$ l of medium $)$, in which they rapidly fixed on the bottom and remained largely $(>80 \%)$ single over a period of $10 \mathrm{~d}(14) . \beta$ cell aggregates were formed in a rotary shaking incubator (16) and then suspended in Lux dishes (Nunc, Naperville, IL) at a concentration of $150 \times 10^{3}$ cells/dish with $3 \mathrm{ml}$ of medium. The preparations were cultured in serum-free conditions developed for rat $\beta$ cells (17). The medium consisted of Ham's F10 (Gibco Laboratories, Grand Island, NY) supplemented with $2 \mathrm{mM}$ L-glutamine, 50 $\mu \mathrm{M}$ 3-isobutyl-1-methylxanthine, 0.075 grams/liter penicillin, 0.1 grams/liter streptomycin, $2 \mathrm{mM}$ calcium chloride, $10 \mathrm{mM}$ glucose, and 5 grams/liter charcoal-treated BSA (fraction V, RIA grade; Sigma Immunochemicals, St. Louis, MO). Stock solutions of cycloheximide $(\mathrm{CHX})^{1}$ were prepared in water $(10 \mathrm{mg} / \mathrm{ml})$, of actinomycin $\mathrm{D}$ (AMD), and antimycin A in DMSO (1 and $10 \mathrm{mg} / \mathrm{ml}$, respectively). These agents were added after the first $20 \mathrm{~h}$ of culture at final concentrations of $1-5 \mu \mathrm{g} / \mathrm{ml} \mathrm{CHX}, 0.1-1 \mu \mathrm{g} / \mathrm{ml} \mathrm{AMD}$, and $0.5 \mu \mathrm{g} / \mathrm{ml}$ antimycin A. The effect of the glucose concentration $(3,6,10$, and $20 \mathrm{mM})$

1. Abbreviations used in this paper: $\mathrm{AMD}$, actinomycin $\mathrm{D}$; $\mathrm{CHX}$, cycloheximide; HO 342, Hoechst 33342; PI, propidium iodide. 

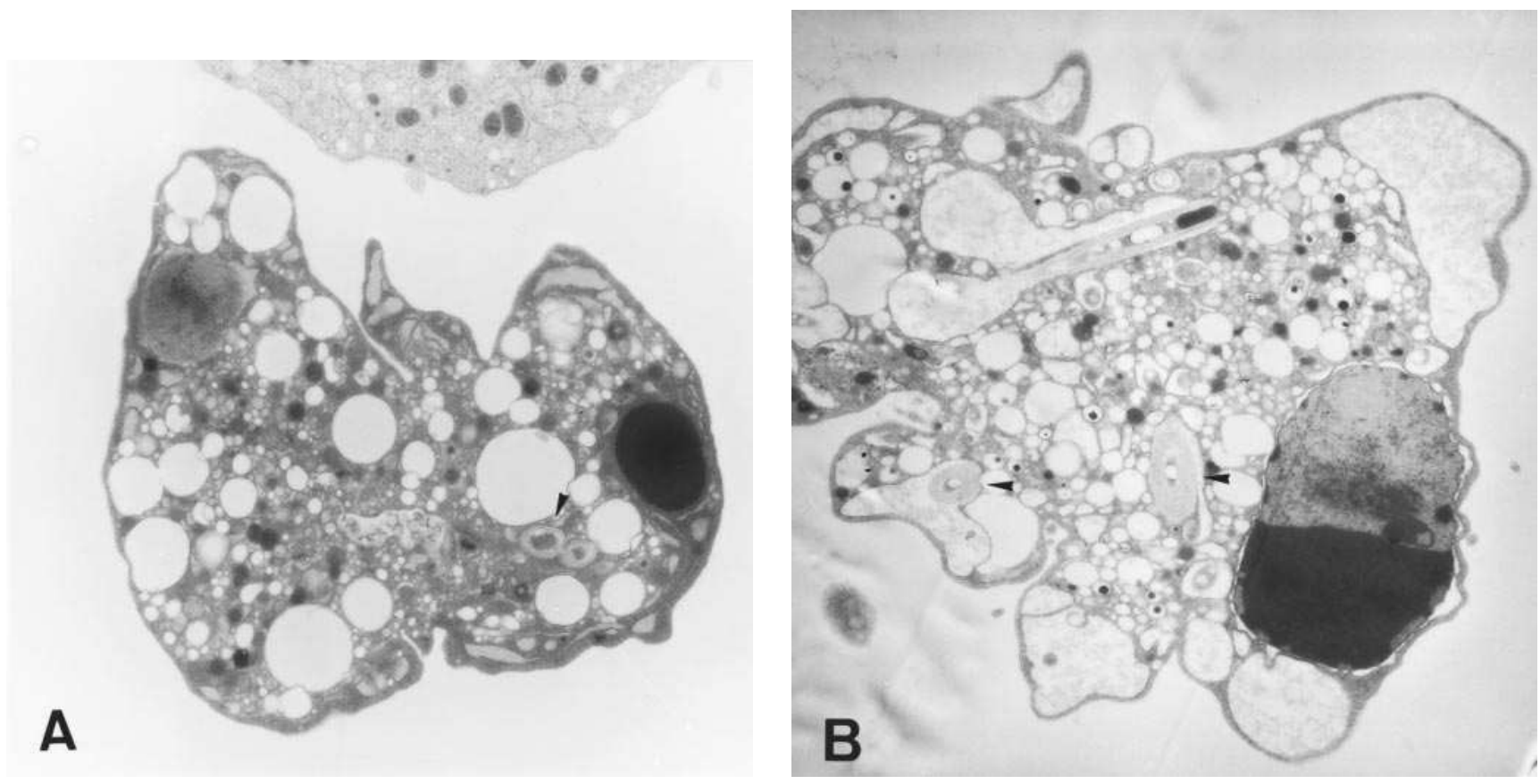

Figure 1. Ultrastructural detection of apoptotic cells in cultures with CHX. Typical characteristics are condensation of the cytoplasm $(A)$, margination of chromatin towards the nuclear membrane $(B)$, condensation and fragmentation of chromatin into spheres $(A)$, and dilatation of the endoplasmic reticulum $(A$ and $B)$. Virtually all apoptotic cells present myelin figures $(A$ and $B$, arrowheads). $A, \times 5,500 ; B, \times 8,500$.

was tested in the above described Ham's medium at $0.3 \mathrm{mM}$ calcium chloride and 10 grams/liter BSA without addition of 3-isobutyl-1-methylxanthine (14).

Electron microscopy. Cells from suspension cultures were fixed in cacodylate-buffered glutaraldehyde (4.5\%, $\mathrm{pH} 7.3)$, postfixed in osmium tetroxide $(1 \%)$, and embedded in Spurr's resin. Ultrathin sections were stained with uranylacetate and lead citrate and exam- ined using a Zeiss EM 109 electron microscope. The $\beta$ cell nature of the apoptotic cells was confirmed by immunogold labeling for insulin. Ultrathin sections were treated for $60 \mathrm{~min}$ with a saturated aqueous solution of sodium metaperiodate at room temperature, washed in $\mathrm{H}_{2} \mathrm{O}$ and preincubated for 10 min in PBS containing 5\% normal goat serum. The sections were then incubated overnight at $4^{\circ} \mathrm{C}$ with guinea pig antiinsulin serum (dilution 1:100 in PBS/0.1\% BSA) and washed
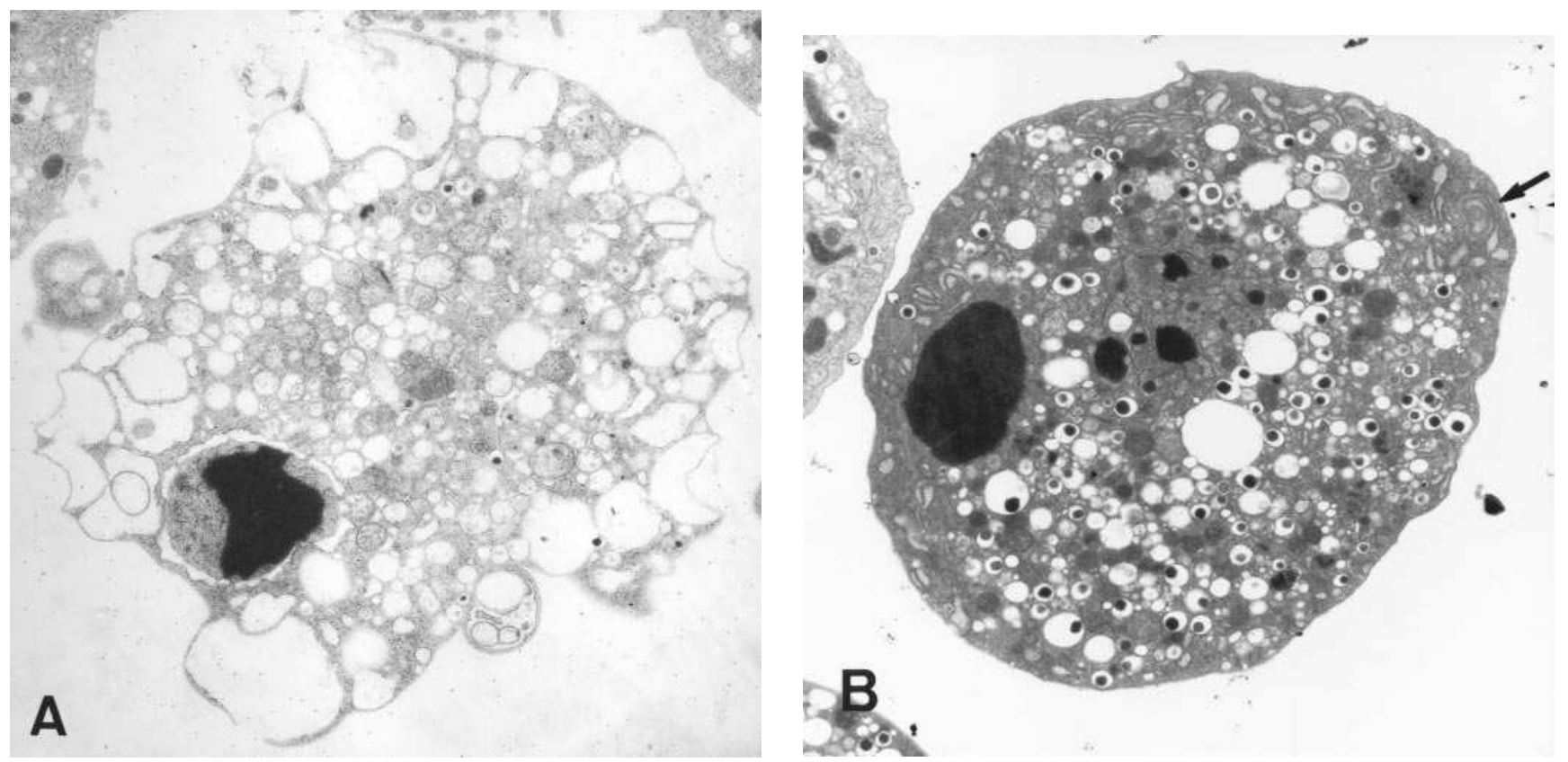

Figure 2. (A) Immunogold labeling for insulin identifying poorly granulated $\beta$ cells as apoptotic $\beta$ cells after culture with $\mathrm{CHX}$. $\times 8,500$. $(B)$ Apoptotic $\beta$ cell after culture at $6 \mathrm{mM}$ glucose, exhibiting dense granulation, condensation of nuclear chromatin, dilatation of endoplasmic reticulum, and a myelin figure (arrow). $\times 7,500$. 
in PBS. The second incubation was performed with a goat antiguinea pig antibody coated with 15-nm diameter colloidal gold complex (Janssen Pharmaceutica, Beerse, Belgium) for $60 \mathrm{~min}$ at room temperature. The sections were washed several times and finally stained with uranylacetate and lead citrate.

Fluorescence microscopic assay. The percentages of viable, necrotic, and apoptotic cells were assessed in the single cell preparations after a culture period of $1,3,5$, or $7 \mathrm{~d}$. For this purpose, the cells were exposed to the DNA binding dyes Hoechst 33342 (HO 342; Calbiochem-Novabiochem Corp., La Jolla, CA) and propidium iodide (PI; Sigma Immunochemicals) (18-20). HO 342 freely passes the plasma membrane and readily enters cells with intact membranes as well as cells with damaged membranes and stains DNA blue, whereas PI, a highly polar dye which is impermeable to cells with preserved membranes, stains DNA red. Medium $(100 \mu \mathrm{l})$ was removed from the microtiter cups and replaced by the same volume containing $20 \mu \mathrm{g} / \mathrm{ml}$ HO 342 and $10 \mu \mathrm{g} / \mathrm{ml}$ PI. After $5 \mathrm{~min}$ of incubation at room temperature, the cells were examined in an inverted fluorescence microscope with ultraviolet excitation at $340-380 \mathrm{~nm}$. Viable or necrotic cells were identified by intact nuclei with, respectively, blue (HO 342) or yellow (HO 342 plus PI) fluorescence. Apoptotic cells were detected by their fragmented nuclei which exhibited either a blue (HO342) or yellow (HO342 plus PI) fluorescence depending on the stage in the process. In early apoptosis, only HO342 will reach the nuclear material, while in the later phase PI will penetrate the cells also (18). In each condition and experiment minimally 1,000 cells were counted. Percentages of living, apoptotic, and necrotic cells were expressed as means \pm SEM. Statistical analysis of differences was calculated by a twosided paired or unpaired $t$ test using a Stat Works computer program.

\section{Results}

Electron microscopical identification of apoptosis. $\beta$ cell aggregates were cultured in the absence or presence of $5 \mu \mathrm{g} / \mathrm{ml}$ CHX for 2, 3, 4, and $5 \mathrm{~d}$. The presence of apoptotic cells was first examined by electron microscopy. Control preparations contained very few apoptotic cells $(<0.5 \%)$, which were identified as contaminating acinar cells on the basis of their zymogen granules. Exposure to $\mathrm{CHX}$ induced apoptosis in insulin-containing $\beta$ cells; after 3 or $4 \mathrm{~d}$ of culture, $4-9 \%$ presented the typical ultrastructural features of apoptosis. This was also the case after exposure to AMD $(1 \mu \mathrm{g} / \mathrm{ml})$, with $13-20 \%$ of the $\beta$ cells exhibiting apoptosis during this time period.

The apoptotic cells were identified on the basis of the following ultrastructural characteristics: condensation and margination of chromatin towards the nuclear membrane or fragmentation of condensed nuclear chromatin into round spheres, condensation of the cytoplasm, dilatation of the endoplasmic reticulum, and budding of the plasma membrane which remains intact (Fig. 1). Numerous laminated membranous structures with the aspect of myelin figures (myelinoid bodies) were observed in apoptotic cells obtained from cultures with CHX or AMD (Fig. 1). In CHX- or AMD-treated preparations, virtually all apoptotic cells presented insulin-containing granules (Fig. $2 \mathrm{~A}$ ). These granules were surrounded by one membrane suggesting that they belong to insulin-producing $\beta$ cells rather than to cells which have ingested secretory vesicles, in which case they should be surrounded by two membranes (21). Apoptotic cells after CHX or AMD treatment contained markedly less insulin granules than control $\beta$ cells. They frequently adhered to nonapoptotic $\beta$ cells, sometimes with desmosomes bridging both cells.

The CHX and AMD-treated preparations exhibited also dead $\beta$ cells with disrupted cytoplasmic membranes. These cells became more numerous with longer culture periods. Most of them displayed features that are reminiscent of apoptotic cells, such as the presence of two or more condensed chromatin spheres (Fig. 3 B). Such features were not encountered in $\beta$ cells which died after exposure to antimycin A (Fig. $3 A$ ). Therefore, they were considered as markers for secondary necrosis which is known to represent a late stage of apoptosis $(1,20)$. Their absence in antimycin A-treated cells indicates that this condition causes primary necrosis.

Fluorescence microscopical assay for apoptosis. After ultrastructural identification of conditions leading to either apoptosis
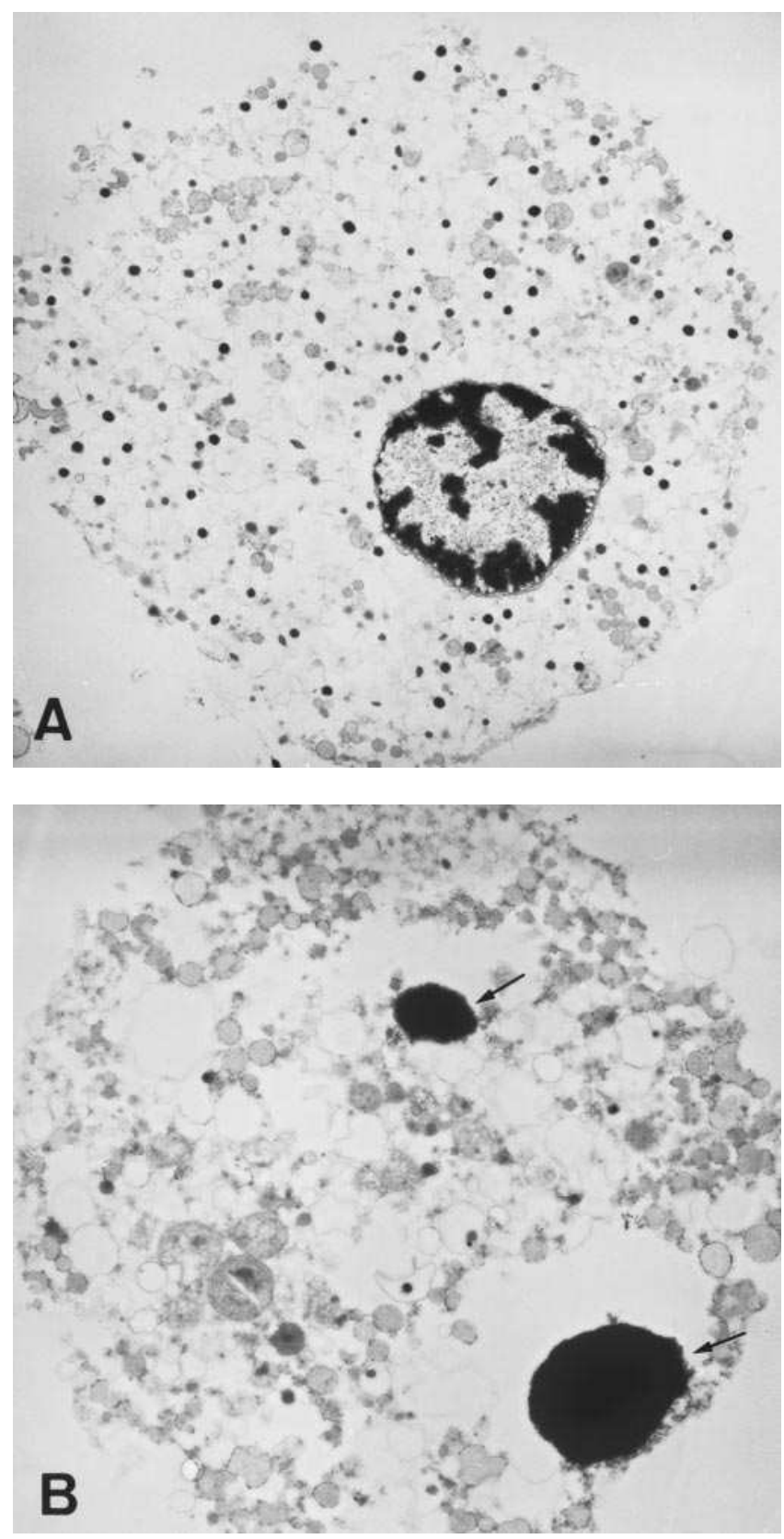

Figure 3. Electron microscopical distinction between $\beta$ cells in primary $(A)$ and secondary $(B)$ necrosis. Both antimycin $(A)$ and CHX $(B)$ treated preparations contained cells with ruptured membranes but only the CHX-treated cells presented nuclear fragmentation ( $a r$ rows). $\times 8,500$. 
or necrosis, we developed a method to distinguish and quantify both processes in a fluorescence microscope (see Methods). Control $\beta$ cell preparations were composed of a majority of cells with one intact and blue fluorescent nucleus (Fig. $4 A$ ). When $\beta$ cells have been exposed to antimycin A $(0.5 \mu \mathrm{g} / \mathrm{ml})$, their nuclei remained intact but exhibited a yellow fluorescence as a result of their binding to both HO 342 (blue) and PI (red); no nuclear fragmentation was observed during the 7-d culture period (Fig. $4 B$ ). Exposure to CHX or AMD caused the appearance of cells with two or more (in some cases up to 10) nuclear fragments with either a blue (only HO342) or yellow (HO342 plus PI) fluorescence (Fig. $4 \mathrm{C}$ ); blue fragmented nuclei correspond to cells in early apoptosis, yellow fragmented nuclei are typical for the late phase when the cells present signs of secondary necrosis (18, and present electron micrographs).

The ability to distinguish cells in both early and late apoptosis allows for the quantification of the number of cells under- going apoptosis over an extended period of time. This is necessary when the cells are not synchronized for their sensitivity to apoptotic conditions (18). We examined whether this is the case for $\beta$ cells exposed to CHX and/or AMD. After $1 \mathrm{~d}$ of culture, the percentage of apoptotic cells was $<5 \%$ in control, CHX, and AMD preparations (Fig. 5). This was still the case in the 7-d cultured control cells. The presence of CHX or AMD induced a time-dependent increase in the number of apoptotic cells; this effect was already clearly detected after $3 \mathrm{~d}$ and affected up to $70 \%$ of the cells after $7 \mathrm{~d}$ (Fig. 5). When CHX was removed after $3 \mathrm{~d}$, the number of apoptotic cells did not further increase during the following $2 \mathrm{~d}$ of culture $(33 \pm 6 \%$ on day 3 vs. $25 \pm 3 \%$ on day $5, P>0.05$ ). When CHX and AMD were added together, $>50 \%$ of the cells exhibited fragmented nuclei after $3 \mathrm{~d}$ of culture. The percentage of necrotic cells remained low in the three conditions (Table I), indicating that $\mathrm{CHX}$ and AMD caused $\beta$ cell death through apoptosis.
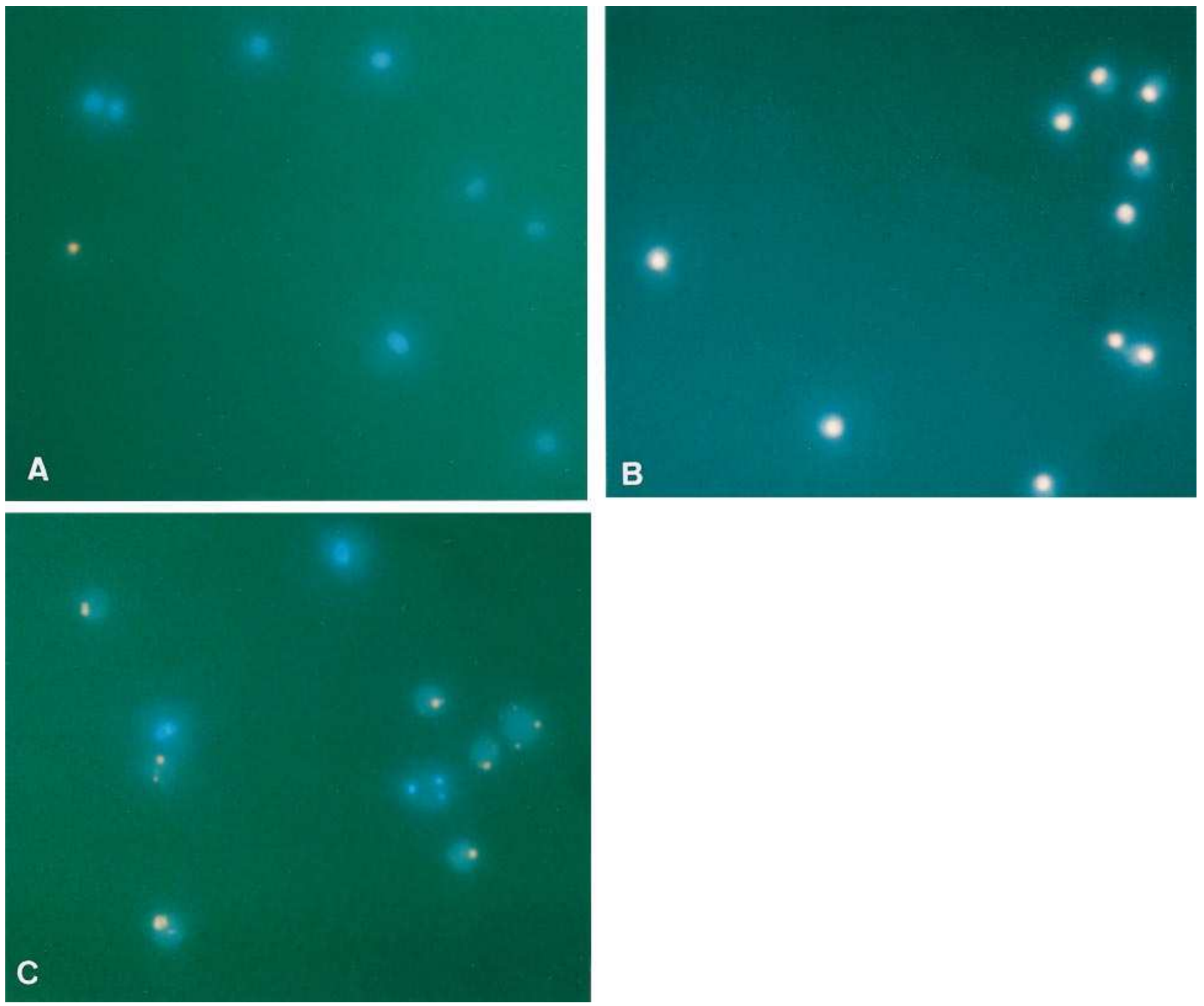

Figure 4. Distinction between living, necrotic, and apoptotic $\beta$ cells by fluorescence microscopy. Cells were cultured for $5 \mathrm{~d}$ in the control condition $(A)$, in the presence of antimycin A $0.5 \mu \mathrm{g} / \mathrm{ml}(B)$, or of CHX $5 \mu \mathrm{g} / \mathrm{ml}(C)$. The control preparation consisted primarily of living cells as indicated by the blue HO-fluorescence of an intact nonfragmented nucleus $(A)$. Exposure to antimycin A results in primary necrosis and leads to a yellow fluorescence of an intact nonfragmented nucleus, which binds both HO 342 and PI $(B)$. Treatment with CHX leads to apoptotic cells which are characterized by fragmented nuclei; blue fluorescence of these fragments indicates an early phase in apoptosis where the cell membrane is still intact, while a yellow fluorescence is an index for cells in the late phase of apoptosis, where the cell membrane integrity is lost $(C)$. $\times 215$. 


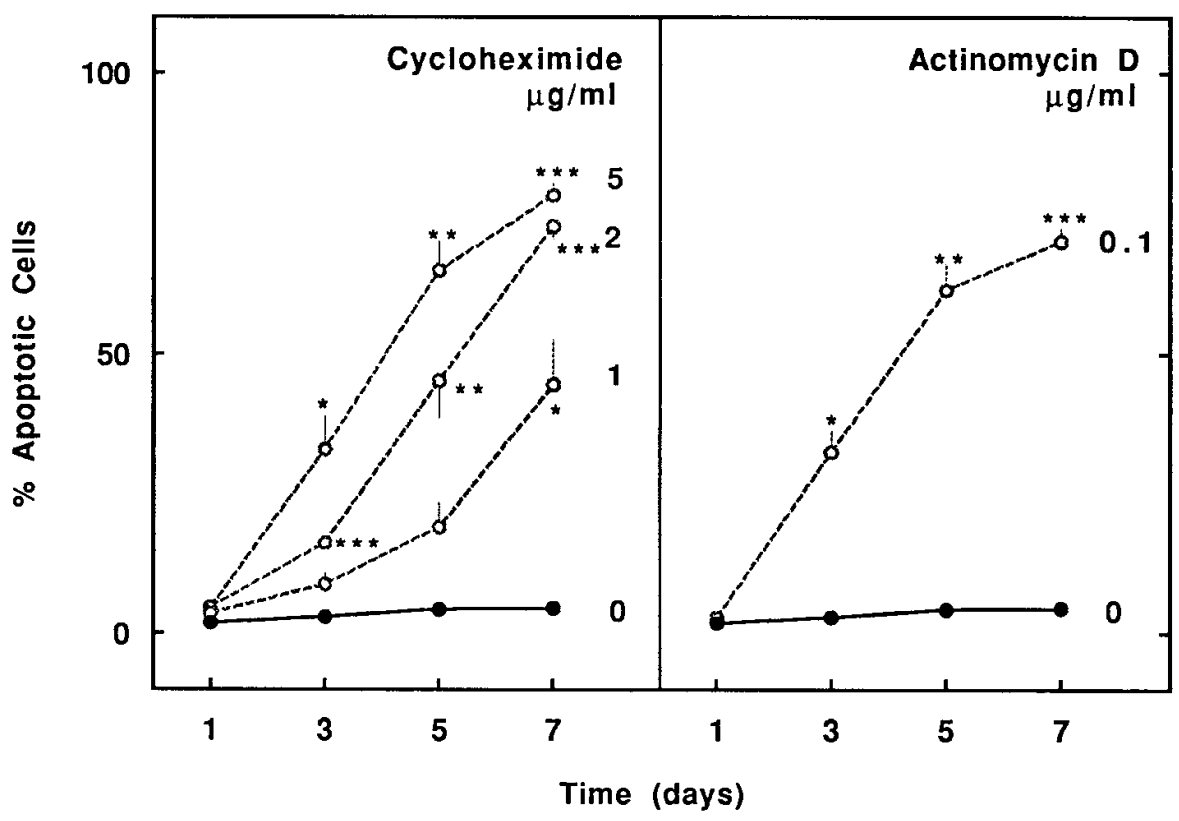

Figure 5. Effect of CHX (left) and AMD (right) on the percentage of apoptotic $\beta$ cells as detected by fluorescence microscopy after $1,3,5$, or $7 \mathrm{~d}$ of culture. Data express means \pm SEM of three or four independent experiments. Statistical significance of differences with control $(0)$ are determined by paired $t$ test analysis. $* P \leq 0.05, * * P \leq 0.01, * * * P \leq 0.001$
Effect of glucose on apoptosis. When the glucose concentration of the medium was reduced from 10 to 6 or $3 \mathrm{mM}$, the percentage of surviving cells decreased dose-dependently; a parallel increase in the percentage of apoptotic cells was noticed, whereas the percentage of necrotic cells was similar in the three conditions (Fig. 6). The use of $20 \mathrm{mM}$ glucose instead of $10 \mathrm{mM}$ did not alter the percentages of apoptotic or necrotic cells. The glucose-dependent survival of cultured $\beta$ cells is thus achieved by suppression of apoptosis (Fig. 6). Electron microscopy confirmed the presence of numerous apoptotic cells after culture at 3 or 6 $\mathrm{mM}$ glucose. At variance with the apoptotic cells after $\mathrm{CHX}$ or AMD treatment, these cells were not severely degranulated and only occasionally presented myelin figures, indicating that these two features are not characteristic of apoptosis (Fig. $2 B$ ).

\section{Discussion}

Identification of factors that induce or prevent apoptosis in a particular cell type is necessary before any physiologic or pathologic role can be attributed to this form of cell death. Such study can be undertaken if the cell type is isolated from its natural environment and cultured under defined conditions

Table I. State of Islet $\beta$ Cells after $7 d$ of Culture

\begin{tabular}{lrccc}
\hline & & \multicolumn{3}{c}{ State of $\beta$ cells* } \\
\cline { 3 - 5 } Culture condition & & Living & Necrotic & Apoptotic \\
\hline & & & $\%$ of total \\
Control & $5 \mu \mathrm{g} / \mathrm{ml}$ & $<5^{\ddagger}$ & $21 \pm 1$ & $78 \pm 2^{\ddagger}$ \\
CHX & $0.1 \mu \mathrm{g} / \mathrm{ml}$ & $<5^{\ddagger}$ & $29 \pm 2$ & $70 \pm 2^{\ddagger}$ \\
AMD & $0.5 \mu \mathrm{g} / \mathrm{ml}$ & $<5^{\ddagger}$ & $98 \pm 1^{\ddagger}$ & $<5$ \\
Antimycin A & & & & \\
& & & & \\
\hline
\end{tabular}

*Determined by fluorescence microscopy. Data are expressed as means \pm SEM from three or four independent experiments. Statistical significance of differences with control condition was calculated by twosided paired $t$ test. ${ }^{\ddagger} P<0.001$. during which the appearance of apoptotic cells is quantified. Apoptotic cells can be identified by ultrastructural characteristics (1); their presence can also be demonstrated by techniques which detect fragmentation of cellular DNA (22). However, quantification of the number of cells undergoing apoptosis faces several difficulties $(18,23)$. When the cells are not synchronized for their sensitivity to apoptotic conditions, longer observation periods are required which can lead to a loss or a considerable overlap of the identification features, such as the labeling pattern of tailing or nick translation techniques (23). Transition to secondary necrosis $(1,20)$ and subsequent cellular disintegration can result in cell losses during preparation for flow cytometric analysis. Contaminating cells can lead to erroneous interpretations in unpurified preparations. The present method overcomes these obstacles.

A fluorescence microscopic assay allows counting of the percentage of apoptotic cells during culture, even after their transition to secondary necrosis. DNA-binding dyes identify the apoptotic cells through their fragmented nuclei; in an early stage, these fragments exhibit blue HO 342 staining, while in a later stage they fluoresce yellow as a result of the additional binding of PI which is known to penetrate the membranes of cells in secondary necrosis. Apoptotic cells in secondary necrosis are easily distinguished from cells in primary necrosis, which are characterized by an intact nucleus. The results of the assay were compatible with parallel observations in electron micrographs.

The use of purified $\beta$ cell preparations avoided misinterpretations as a result of cellular contamination. Previously, we developed methods for the purification of adult rat $\beta$ cells and their culture under serum-free conditions (14-17). A medium was defined in which $>80 \%$ of the cells survive during $10 \mathrm{~d}$ of culture $(14,17)$. It is now shown that the cells dying in this condition do not exhibit signs of apoptosis. However, a block of protein synthesis or mRNA formation leads to apoptosis of $\beta$ cells from the second day of culture. From this time on, progressively more $\beta$ cells undergo apoptosis and subsequent secondary necrosis, up to $70 \%$ after $7 \mathrm{~d}$. The process of apoptosis is clearly evidenced by the ultrastructural features that are typ- 


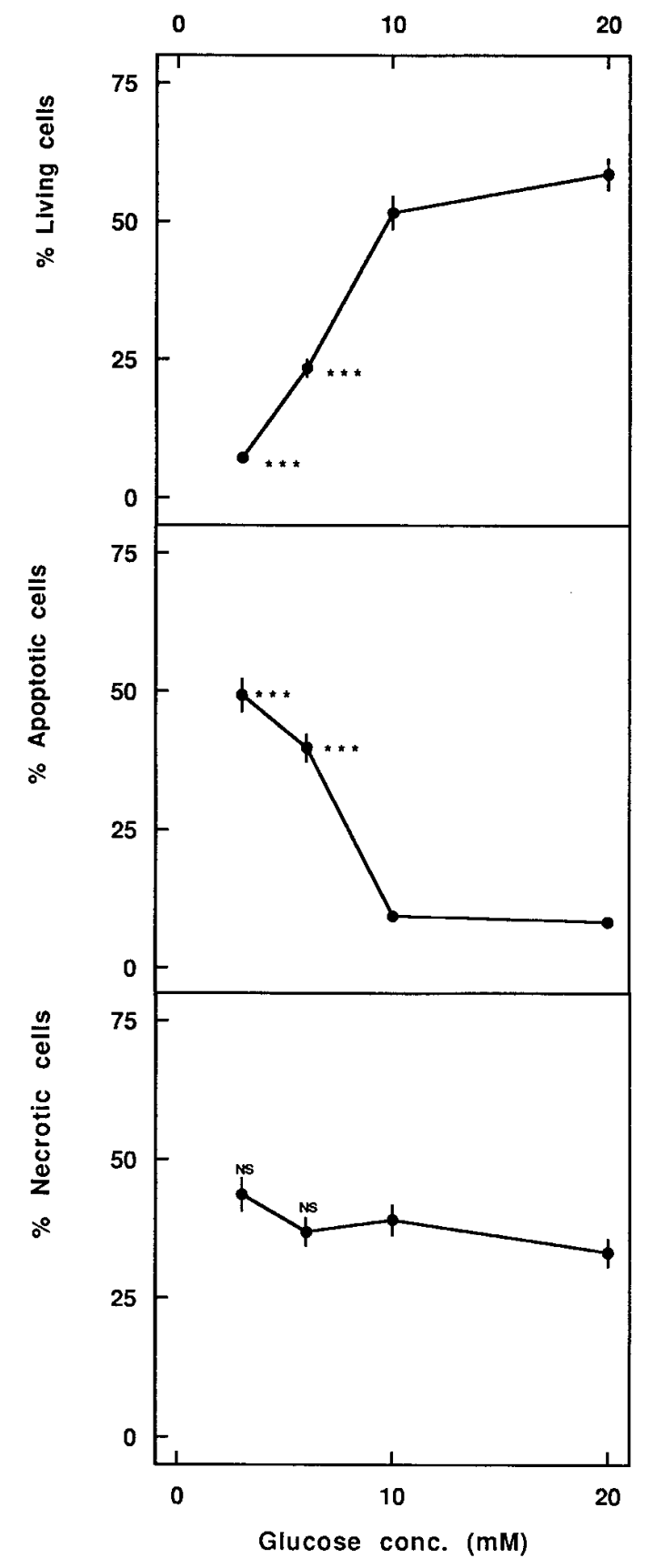

Figure 6. Effect of glucose concentration during $8 \mathrm{~d}$ of culture on the percentages of living, apoptotic, and necrotic $\beta$ cells as detected by fluorescence microscopy. Data express means \pm SEM of nine independent experiments. Statistical significance of differences between 3 and $10 \mathrm{mM}$ glucose and between 6 and $10 \mathrm{mM}$ glucose is calculated by paired $t$ test. $* * * P \leq 0.001$, NS (nonsignificant) $P>0.05$.

ical for this form of cell death such as condensation and margination of chromatin and its fragmentation, dilatation of endoplasmic reticulum, and budding of membranes (1). Degranulation and the presence of myelin-like structures are not characteristic for apoptotic $\beta$ cells as these features are much less prominent when apoptosis was caused by a reduction in glucose levels. Myelin figures may result from cellular incorporation of drugs such as $\mathrm{CHX}$ and AMD, which could inhibit membrane digestion (24). With the transition to secondary necrosis, the ultrastructural signs of apoptosis became less prominent, making electron microscopy less suited for a distinction from primary necrotic cells. The presently developed fluorescence microscopic assay allows detection of apoptotic cells in both the early and late phases of this type of cell death. Throughout the culture period, these cells remained clearly distinguishable from those which died from primary necrosis, such as after exposure to the mitochondrial poison antimycin A.

The observation that adult rat $\beta$ cells undergo apoptosis when their RNA or protein synthesis is blocked strongly suggests that the normal protein synthetic activity of these cells suppresses a constitutively expressed apoptotic program. In other words, survival of $\beta$ cells depends on their production of factors which inhibit an endogenous suicide program. That the synthesis of such protective factors is blocked more effectively when CHX and AMD are added together has already been observed in other cell types (7), possibly resulting from an additional action of one of these drugs such as DNA damage caused by AMD, a DNA intercalating agent (25). Most $\beta$ cells can overcome a 1-d period without protein synthesis, but longer periods lead to a progressive increase in the number of apoptotic cells. That $\beta$ cells differ in their individual sensitivity to a block in transcription or translation is a further illustration of the functional heterogeneity in the pancreatic $\beta$ cell population (26). We have shown previously that individual $\beta$ cells differ in their protein synthetic activity (27). A proportion of $\beta$ cells is already biosynthetically active at low $(3 \mathrm{mM})$ glucose, while the other cells become activated at higher glucose concentrations up to $10 \mathrm{mM}$. The dose-dependent recruitment of $\beta$ cells into biosynthetic activity is attributed to an intercellular heterogeneity in the metabolic threshold for glucose metabolism (28). Prolonged exposure to $10 \mathrm{mM}$ glucose maintains the majority of $\beta$ cells in an activated state $(28,29)$; in this condition, the rates of cell death and of apoptosis (14, and present data) are low. Culture at lower glucose concentration results in lower percentages of activated $\beta$ cells $(10 \mathrm{mM}>6 \mathrm{mM}>3$ $\mathrm{mM})(28,29)$, and increased percentages of dying cells (14 and present data). The present study demonstrates that the increased cell death at lower glucose concentration is the end point of an apoptotic process. In view of the data after treatment with CHX and AMD, it can be concluded that the prolonged inactive state of the glucose-unresponsive $\beta$ cells makes them sensitive to apoptotic conditions. The extent of apoptotic $\beta$ cell death will depend on the number of cells which have remained inactive for $2 \mathrm{~d}$ or longer. The existence of an intercellular heterogeneity in glucose sensitivity will thus be responsible for intercellular differences in sensitivity to an apoptotic process.

So far, apoptotic $\beta$ cells have only been sporadically observed in vivo (30-32). According to the present observations, this may result from the intercellular differences in sensitivity to apoptotic conditions and the short duration of the phase with the ultrastructural characteristics of cellular apoptosis. The phenomenon has been described in vitro but the underlying mechanism has not yet been identified (33). The present study indicates that adult rat $\beta$ cells express an apoptotic program which is activated after prolonged suppression of RNA and protein formation. Survival of $\beta$ cells thus seems dependent on production of particular proteins which inhibit an endogenous suicide program. The glucose sensitivity of the individual $\beta$ cells determines their potential to suppress their 
apoptotic program. Sustained reduction in this glucose sensitivity (or in glucose concentration) may thus result in increased cell death. Among the future questions to be addressed, it will be important to examine whether exogenous survival factors, other than glucose exist which stimulate $\beta$ cells to synthesize the putative proteins that suppress their apoptotic program (3). Identification of these factors can be undertaken in the presently described model for detection of apoptosis. Deprivation of such signals or cellular unresponsiveness to their message may well result in $\beta$ cell losses, leading to activation of the immune system and development of diabetes. Such phenomenon would certainly add strong support to the view that apoptosis plays an important role in the pathogenesis of autoimmune and degenerative diseases $(11,34)$.

\section{Acknowledgments}

The authors thank the technical staff of the Diabetes Research Center at the Vrije Universiteit Brussel for expert assistance.

This work was supported by grants from the Belgian Fund for Scientific Research (3.0093.90 and 3.3132.91) and from the Flemish Community (Concert action 92/97-1807). Anne Hoorens is a research fellow of the Belgian National Fund for Scientific Research.

\section{References}

1. Wyllie, A.H., J.F.R. Kerr, and A.R. Currie. 1980. Cell death: the significance of apoptosis. Int. Rev. Cytol. 68:251-306.

2. Steller, H. 1995. Mechanisms and genes of cellular suicide. Science (Wash. DC). 267:1445-1449.

3. Raff, M.C., B.A. Barres, J.F. Burne, H.S. Coles, Y. Ishizaki, and M.D. Jacobson. 1993. Programmed cell death and the control of cell survival: lessons from the nervous system. Science (Wash. DC). 262:695-700.

4. Martin, D.P., R.E. Schmidt, P.S. DiStefano, O.H. Lowry, J.G. Carter, and E.M. Johnson, Jr. 1988. Inhibitors of protein synthesis and RNA synthesis prevent neuronal death caused by nerve growth factor deprivation. J. Cell Biol. 106:829-844.

5. Martin, S.J. 1993. Apoptosis: suicide, execution or murder? Trends Cell Biol. 3:141-144.

6. Dremier, S., J. Golstein, R. Mosselmans, J.E. Dumont, P. Galand, and B. Robaye. 1994. Apoptosis in dog thyroid cells. Biochem. Biophys. Res. Commun. 200:52-58.

7. Martin, S.J., S.V. Lennon, A.M. Bonham, and T.G. Cotter. 1990. Induction of apoptosis (programmed cell death) in human leukemic HL-60 cells by inhibition of RNA or protein synthesis. J. Immunol. 145:1859-1867.

8. Ledda-Columbano, G.M., P. Coni, G. Faa, G. Manenti, and A. Columbano. 1992. Rapid induction of apoptosis in rat liver by cycloheximide. Am. J. Pathol. 140:545-549.

9. Ijiri, K., and C.S. Potten. 1987. Further studies on the response of intestinal crypt cells of different hierarchical status to eighteen different cytotoxic agents. Br. J. Cancer. 55:113-123.

10. Ishizaki, Y., J.F. Burne, and M.C. Raff. 1994. Autocrine signals enable chondrocytes to survive in culture. J. Cell Biol. 126:1069-1077.

11. Thompson, C.B. 1995. Apoptosis in the pathogenesis and treatment of disease. Science (Wash. DC). 267:1456-1462.

12. Gepts, W. 1965. Pathologic anatomy of the pancreas in juvenile diabetes mellitus. Diabetes. 14:619-633.

13. Pipeleers, D., and Z. Ling. 1992. Pancreatic beta cells in insulin-depen- dent diabetes. Diabetes Metab. Rev. 8:209-227.

14. Ling, Z., J.C. Hannaert, and D. Pipeleers. 1994. Effect of nutrients, hormones and serum on survival of rat islet beta cells in culture. Diabetologia. 37 : 15-21.

15. Pipeleers, D.G., P.A. In’t Veld, M. Van De Winkel, E. Maes, F.C. Schuit, and W. Gepts. 1985. A new in vitro model for the study of pancreatic A and B cells. Endocrinology. 117:806-816.

16. Pipeleers, D.G., F.C. Schuit, P.A. In't Veld, E. Maes, E.L. Hooghe-Peters, M. Van De Winkel, and W. Gepts. 1985. Interplay of nutrients and hormones in the regulation of insulin release. Endocrinology. 117:824-833.

17. Ling, Z., and D.G. Pipeleers. 1994. Preservation of glucose-responsive islet $\beta$-cells during serum-free culture. Endocrinology. 134:2614-2621.

18. Dive, C., C.D. Gregory, D.J. Phipps, D.L. Evans, A.E. Milner, and A.H. Wyllie. 1992. Analysis and discrimination of necrosis and apoptosis (programmed cell death) by multiparameter flow cytometry. Biochim. Biophys. Acta. 1133:275-285.

19. Hardin, J.A., D.H. Sherr, M. DeMaria, and P.A. Lopez. 1992. A simple fluorescence method for surface antigen phenotyping of lymphocytes undergoing DNA fragmentation. J. Immunol. Methods. 154:99-107.

20. Vitale, M., L. Zamai, G. Mazzotti, A. Cataldi, and E. Falcieri. 1993. Differential kinetics of propidium iodide uptake in apoptotic and necrotic thymocytes. Histochemistry. 100:223-229.

21. In't Veld, P.A., and D.G. Pipeleers. 1988. In situ analysis of pancreatic islets in rats developing diabetes: appearance of nonendocrine cells with surface MHC class II antigens and cytoplasmic insulin immunoreactivity. J. Clin. Invest. 82:1123-1128.

22. Wyllie, A.H. 1980. Glucocorticoid-induced thymocyte apoptosis is associated with endogenous endonuclease activation. Nature (Lond.). 284:555-556.

23. Gold, R., M. Schmied, G. Giegerich, H. Breitschopf, H.P. Hartung, K.V. Toyka, and H. Lassmann. 1994. Differentiation between cellular apoptosis and necrosis by the combined use of in situ tailing and nick translation techniques. Lab. Invest. 71:219-225.

24. Ghadially, F.N. 1975. Ultrastructural Pathology of the Cell: A Text and Atlas of Physiological and Pathological Alterations in Cell Fine Structure. Butterworths, London. 543 pp.

25. Tishler, R.B., S.K. Calderwood, C.N. Coleman, and B.D. Price. 1993. Increases in sequence specific DNA-binding by p53 following treatment with chemotherapeutic and DNA damaging agents. Cancer Res. 53(Suppl. 10):22122216.

26. Pipeleers, D.G. 1992. Heterogeneity in pancreatic $\beta$-cell population. $D i$ abetes. 41:777-781.

27. Schuit, F.C., P.A. In’t Veld, and D.G. Pipeleers. 1988. Glucose stimulates proinsulin biosynthesis by a dose-dependent recruitment of pancreatic beta cells. Proc. Natl. Acad. Sci. USA. 85:3865-3869.

28. Kiekens, R., P.A. In't Veld, T. Mahler, F. Schuit, M. Van De Winkel, and D. Pipeleers. 1992. Differences in glucose recognition by individual rat pancreatic B cells are associated with intercellular differences in glucose-induced biosynthetic activity. J. Clin. Invest. 89:117-125.

29. Ling, Z., R. Kiekens, T. Mahler, F.C. Schuit, M. Pipeleers-Marichal, A. Sener, G. Klöppel, W.J. Malaisse, and D.G. Pipeleers. 1996. Effects of chronically elevated glucose levels on the functional properties of rat pancreatic beta cells. Diabetes. In press.

30. Finegood, D.T., L. Scaglia, and S. Bonner-Weir. 1995. Dynamics of $\beta$-cell mass in the growing rat pancreas: estimation with a simple mathematical model. Diabetes. 44:249-256.

31. Scaglia, L., F.E. Smith, and S. Bonner-Weir. 1995. Apoptosis contributes to the involution of $\beta$ cell mass in the post partum rat pancreas. Endocrinology. 136:5461-5468.

32. Blume, N., J. Skouv, L.-I. Larsson, J.J. Holst, and O.D. Madsen. 1995 Potent inhibitory effects of transplantable rat glucagonomas and insulinomas on the respective endogenous islet cells are associated with pancreatic apoptosis. J. Clin. Invest. 96:2227-2235.

33. Lorenzo, A., B. Razzaboni, G.C. Weir, and B.A. Yanker. 1994. Pancreatic islet cell toxicity of amylin associated with type-2 diabetes mellitus. Nature (Lond.). 368:756-760.

34. Nagata, S., and P. Golstein. 1995. The Fas death factor. Science (Wash. DC). 267:1449-1456. 